\title{
Anna Wolff-Powęska, Pamięć - brzemię i uwolnienie. Niemcy wobec nazistowskiej przeszłości (1945-2010), Zysk i s-ka, Poznań 2011, ss. 582
}

\section{(c) $(1) \ominus$}

\ażdy, kto w Polsce zajmuje się problematyką niemiecką, musiał się zeItknąć z dorobkiem naukowym Anny Wolff-Powęskiej. Związana ze stolicą Wielkopolski historyk i politolog, wieloletnia dyrektor zasłużonego Instytutu Zachodniego, nieraz podejmowała wysiłek analizy tematów trudnych i wcześniej mało znanych, a jednocześnie ważnych i kontrowersyjnych. Wśród pisarskiego dorobku profesor Uniwersytetu im. Adama Mickiewicza można wymienić m.in. prace dotyczące niemieckiej geopolityki, konserwatyzmu w Republice Federalnej Niemiec, stosunku Polaków wobec Niemców w czasach PRL czy też postaw niemieckich Kościołów wobec żydowskich współobywateli. W nurcie tych ambitnych fascynacji naszymi zachodnimi sąsiadami i ich skomplikowaną historią mieści się też najnowsza książka Wolff-Powęskiej: Pamięć - brzemię i uwolnienie. Niemcy wobec nazistowskiej przesztości (1945-2010), która została wydana w 2011 r. przez poznańskie wydawnictwo Zysk i s-ka. W tym miejscu należy od razu wyrazić uznanie dla tej ambitnej oficyny wydawniczej, gdyż recenzowana tu publikacja może pod względem edytorsko-redakcyjnym stanowić wzór solidnej - wręcz „wielkopolskiej” - pracy.

Oprócz wprowadzenia i naprawdę imponującej bibliografii (na 50 stronach!), Pamięć - brzemię i uwolnienie składa się z pięciu rozdziałów i licznych w nich podrozdziałów. Na prawie 600 stronach swojego dzieła autorka starała się zachować układ chronologiczny, co można uznać za wprawdzie mało pomysłową, ale bez wątpienia najlogiczniejszą konstrukcję . W praktyce, przy omówieniach poszczególnych zagadnień szczegółowych nieraz owej chronologii wykładu nie udaje się zachować, co jednak, biorąc pod uwagę sam temat i wykorzystane przy jego opracowaniu źródła, jest raczej oczywiste i nie może być traktowane jako zarzut. Na pięć rozdziałów składa się wprowadzenie w temat przygotowane pod kątem filozoficzno-metodologicznym (rozdział I: „Mnemosyne - matka muz”), przedstawie- 
nie tematu w kontekście trzech epok powojennych dziejów Niemiec (rozdziały II-IV) oraz analiza poszczególnych świąt, uroczystości i jubileuszy (rozdział V: „Święta pamięci”), mniej lub bardziej ochoczo obchodzonych przez Niemców po 1945 r. Rozdział drugi („Między końcem a początkiem”) został poświęcony okresowi bezpośrednio powojennemu, rozdział trzeci („Podzielony naród, podzielona pamięć”) okresowi istnienia dwóch państw niemieckich, a rozdział czwarty („Republika berlińska: maraton pamięci”) ostatniemu, trwającemu już ponad 20 lat, okresowi historii znów zjednoczonego państwa i - chyba jednak nie tak do końca - zjednoczonego narodu.

W całej książce wielorakim analizom poddano imponującą liczbę zagadnień szczegółowych i dlatego też w recenzji chyba najbardziej właściwe wydaje się podążanie - prawie strona za stroną - tropem rozważań WolffPowęskiej. Już na początku rozdziału pierwszego za ciekawe i ważne należy uznać przypomnienie Mnemosyne (bogini pamięci), co pozwala nam na refleksje na temat związków współczesnej myśli i idei z ich antyczną genezą. Prawie na aplauz w całym tym rozdziale zasługuje to, że autorka dużo uwagi poświęca nie tylko „Pamięci”, ale też jej przeciwieństwom: „niepamięci” i „zapomnieniu” - może bowiem okazać się, że to właśnie one są ważniejsze i istotniejsze wtedy, gdy chcemy badać szeroko rozumianą świadomość społecznych zbiorowości. Od razu można tu zadać sobie jedno zasadnicze pytanie: czy coś takiego jak „pamięć zbiorowa” (s. 26) rzeczywiście istnieje? Autorka, omawiając dociekania różnych badaczy (przede wszystkim filozofów i historyków) w tym względzie, samej istoty jej istnienia nie poddaje jednak analizie. Już przy zetknięciu się z jej uwagami na ten temat, można wyrazić kolejną wątpliwość: co mianowicie autorka miała na myśli, pisząc, że „w warunkach demokracji” następuje „prywatyzacja pamięci” i „przybywa aktorów, których interesy pamięci i niepamięci znajdują się często w konflikcie" (s. 29)? Myśl to ciekawa, ale może należałoby ją nieco rozwinąć, by czytelnik średnio zaznajomiony z tematem wiedział, co konkretnie ma tu na myśli poznańska uczona. W związku z tą uwagą należy się zastanowić, czy owa „demokracja” odgrywa aż tak dużą rolę „w szukaniu dialogu dla poszczególnych wspólnot pamięci” (s. 34). Czy przypadkiem ważniejsza od „demokracji” nie jest „wolność”? Kilkanaście stron dalej autorka dokonuje interesującego porównania „pamięci komunizmu” i „pa- 
mięci nazizmu” (jako „zimnej” i „gorącej”) za Charlesem S. Maierem (s. 57) oraz przypomina definicję istoty "polityki historycznej” Edgara Wolfruma (s. 67-69). W tym pierwszym przypadku brakuje jednak precyzyjnego wyjaśnienia, co Maier właściwie chciał przez to powiedzieć. Jednocześnie Wolff-Powęska formułuje godną przytoczenia i rozpropagowania uwagę, że w Polsce w ostatnich latach pojęcie "polityki historycznej” jest obecne w charakterze

sloganu medialnego, hasła, postulatu politycznego lub argumentu w polityczno-historycznych kontrowersjach, częściej wypełnianego emocjami aniżeli poszukiwaniem sensu poznawczego (s. 69).

Natomiast z kolejną jej opinią, że w ostatnich latach w Polsce tylko dwa historyczne tematy (Jedwabne w stosunkach polsko-żydowskich i Centrum przeciw Wypędzeniom w stosunkach polsko-niemieckich) „skupiły na dłużej uwagę publiczną" (s. 74), należy chyba polemizować. Czy nie wystarczy tu przypomnieć chociażby kwestię oceny obrad Okrągłego Stołu, a ostatnio tragedię smoleńską? Poza tym, czy mówimy tu o uwadze i zainteresowaniach rzeczywiście opinii publicznej, czy też raczej mediów, elit, polityków itd.? W poświęconym tym zagadnieniom podrozdziale („Historyk między mediami i polityką") można było też wspomnieć o rozważaniach Neila Postmana, a pisząc o „demokratyzacji” historii (s. 77), chyba lepiej byłoby wspomnieć o jej „egalitaryzacji”. Natomiast już w zakończeniu pierwszego rozdziału Wolff-Powęska, analizując postawy i zadania współczesnych badaczy przeszłości w odniesieniu do polityki pamięci, co do ich postawy wykazuje spory optymizm (s. 98-102) - czy nie zbyt duży? Wielu historyków jest przecież bardzo łasych na konfitury medialnej popularności i politycznych wpływów, co rzadko można pogodzić z ich naukową rzetelnością i obiektywizmem.

W rozdziale drugim autorka omawia niemiecką „pamięć” przede wszystkim w czterech pierwszych powojennych latach, a pewne wątpliwości wzbudza już sam jego tytuł - „Między końcem a początkiem”. Jasne jest, co tu było „końcem” - klęska w maju 1945 r. Ale co jest „początkiem? Czyżby powstanie dwóch państw niemieckich? Można się natomiast zgodzić z przedstawionymi przez nią dalej (s. 108) ocenami znaczenia drugiej 
wojny światowej, chociaż od razu wypada dodać, że dla niektórych osób pamiętających pierwszą wojnę światową (np. głód w niemieckich miastach czy cztery lata spędzone w okopach) przeżycia mogły być nie mniej traumatyczne. Warto tam było też wspomnieć, że wojny totalne - wprawdzie nie na taką skalę jak druga światowa - zdarzały się już wcześniej.

Pisząc w tym rozdziale o powojennym „Przezwyciężaniu przeszłości” Wolff-Powęska wspomina też małżeństwo Mitscherlichów (s. 124-125), głównie jako „psychoanalityków”, choć dla tematu jej książki chyba za znacznie istotniejszy fakt należałoby uznać to, że w latach powojennych $\mathrm{dr}$ Alexander Mitscherlich był obserwatorem norymberskiego procesu lekarzy i jednym z niewielu spośród niemieckich medyków próbujących uczciwie rozliczyć zbrodnie swoich kolegów z czasów Trzeciej Rzeszy*. Szczególnie zapoznając się z niemiecką „Winą i wstydem” czytelnik napotka na ten temat wiele bardzo ciekawych opinii reprezentantów pokonanego w 1945 r. narodu, lecz są to w olbrzymiej większości sądy wyrażane przez intelektualistów, a nie „zwykłych ludzi”. Śmiem wątpić, że brakuje opinii tych drugich, choć zapewne były one mniej nośne i przemyślane. Trzeba tu wspomnieć, że nieliczne w całej książce wyjątki od zasady prezentowania głównie opinii elit znajdują się w podrozdziale „Uczciwi mordercy” (s. 173-175), choć i w nim większość wynurzeń pochodzi od samego Heinricha Himmlera. Autorka zauważa jednak niewątpliwą „bezradność” owych intelektualistów wobec nazistowskiej przeszłości (s. 151-157). Szkoda, że dalej - w podrozdziale „Niewinni zbrodniarze” - w ogóle nie

Wspomniano o tym w książce wydanej w Polsce prawie równocześnie z recenzowaną pracą (opracowanej w związku z wcześniej wyreżyserowanym filmem dokumentalnym) Norberta Freia (N. Frei, Kariery w pótmroku. Hitlerowskie elity po 1945 roku, Warszawa 2011), której tematyka w wielu kwestiach pokrywa się z dociekaniami Anny Wolff-Powęskiej. Można tu dodać, że poziom opracowania polskiej badaczki trzeba uznać za ciekawszy i naukowo bardziej wartościowy, chociaż lektura tekstów Freia i kilku z nim współpracujących autorów też może nam dostarczyć wielu informacji o osobistych lub też zbiorowych amnezjach w odniesieniu do nazistowskiej przeszłości pośród pięciu elitarnych grup zawodowych (lekarzy, przedsiębiorców, wojskowych, prawników i dziennikarzy). W porównaniu z pracą zachodnioniemieckich historyków, dociekania Wolff-Powęskiej charakteryzują się większym obiektywizmem, mniejszą polityczną poprawnością, a przy tym potrafiła ona znacznie krytyczniej ocenić rzeczywiste intencje i cele wieloletnich zabiegów wschodnioniemieckich propagandzistów z NRD. 
rozważa się ewentualności, iż wojenni przestępcy w większości naprawdę wierzyli w słuszność swojej życiowej drogi oraz - niejako będącą pochodną tego - swoją niewinność. W ich przypadku niekoniecznie pojawiało się wyłącznie „uspokajanie” własnego sumienia, lecz w świadomości tych katów mogła tkwić autentyczna wiara w słuszność racji i argumentów głoszonych przez lata. Natomiast pisząc o „trywialnej literaturze i produkcji filmowej”, które odzwierciedlały „mit narodu zniewolonego, uwiedzionego przez Hitlera” (s. 181), warto było (chociaż w przypisie) podać klika ich przykładów. W zakończeniu tego podrozdziału aż na kilku stronach WolffPowęska ocenia denazyfikację. Uznaje ją ze znakiem zapytania za „nieudany eksperyment”, stwierdza następnie, że „potrzeba było wielu lat, by dostrzec jej ostatecznie pozytywny bilans" (s. 209). Niestety na czym on polegał i jakie były jego najważniejsze przejawy czytelnik, musi się już domyśleć sam.

Znacznie mniej kontrowersji może wywołać lektura rozdziału trzeciego. Szczególnie dwa pierwsze jego podrozdziały („Zwycięzcy historii: Niemiecka Republika Demokratyczna w cieniu antyfaszyzmu” oraz „Obciążeni historią: Republika Federalna Niemiec między mitem a pamięcią”) należy uznać za wspaniale napisane i interesujące. Wśród wszystkich jego treści szczególne warte przedstawienia są informacje o historycznej abnegacji Niemców i to w zaledwie 15 lat po zakończeniu wojny (s. 292), a wątpliwości mogą wzbudzać jedynie dwie kwestie. Po pierwsze, Victor Klemperer był wprawdzie „niemieckim romanistą” (s. 302), ale dla jego naukowego i pisarskiego dorobku chyba ważniejsze były przeżycia jako osoby o żydowskich korzeniach. Po drugie, wypadałoby wyjaśnić, na czym polegał wspomniany „skandal „Bitburga” (s. 315). Już pod koniec tego rozdziału autorka przypomina bardzo ważną i ciekawą dyskusję, jaką w latach osiemdziesiątych XX wieku toczyli zachodnioniemieccy historycy. U jej podstaw znajdowały się kontrowersyjne, aczkolwiek niepozbawione sensu opinie Ernsta Noltego i Andreasa Hillgrubera (s. 317 i n.) W przypadku niektórych przypomnianych i cytowanych w publikacji Wolff-Powęskiej zachodnioniemieckich „postępowych” czy też „lewicowych” intelektualistów może warto byłoby zainteresować się też ich kontaktami (najczęściej pośrednimi) z wywiadem wschodnioniemieckim. Był to przecież wielki i znaczący problem „republiki bońskiej”, który zresztą z wiadomych względów światło dzienne ujrzał dopiero po 1990 r., czyli już w „republice berlińskiej”. 
Dyskusji tej (zatytułowanej „Maraton pamięci”) został poświęcony rozdział czwarty recenzowanej tu pracy. Przede wszystkim zaprezentowano w nim „Debaty, które zmieniły Niemcy”: ciekawy i właściwie broniący się przed krytyką (tym bardziej że autorka wspomina również o innych kwestiach, jakie wywoływały w Niemczech ponadprzeciętne zainteresowanie oraz gorące dyskusje) wybór czterech tematów, które w ostatnim dwudziestoleciu zdominowały niemiecki dyskurs o nazistowskiej przeszłości. Niejako za znamienny, choć pewnie nie dla każdego zrozumiały i bezdyskusyjny, można uznać fakt, że aż trzy z nich dotyczą przede wszystkim Holocaustu.

Pierwsza z debat rozgorzała w związku z wystawą prezentującą zbrodnie Wehrmachtu. Trudno ją oczywiście z perspektywy niezwiedzającego recenzenta oceniać, choć można przypuszczać, że autorom być może bardziej zależało na prowokacji i rozgłosie niż prezentacji rzetelnej wiedzy. Można tu też dodać, że akurat wojna na terenie ZSRR czy byłej Jugosławii (jedne z głównych tematycznych elementów ekspozycji) była prowadzona z niebywałym okrucieństwem przez wszystkie strony konfliktu. W analizie tej wystawy pióra Wolff-Powęskiej wyjątkowo interesujące są natomiast informacje o badaniach reakcji zwiedzających pod kątem ich generacyjnej przynależności.

Druga z debat była związana $\mathrm{z}$ ukazaniem się w Niemczech książek Daniela J. Goldhagena. Autorka słusznie nie pomija faktu, że jest on Amerykaninem o żydowskich korzeniach, oraz ma rację, pisząc nieco tajemniczo, że „główne credo amerykańskiego autora jest bezsprzecznie sporne" (s. 353). Pomija ona jednak przypuszczalnie komercyjny cel całej tej debaty, gdyż chyba nie można wykluczać ewentualności, że gra w niej nie toczyła się bynajmniej o rozpoczęcie jakichkolwiek naukowych dyskusji, lecz o liczbę sprzedanych egzemplarzy Gorliwych katów Hitlera. Cel ten udało się Goldhagenowi osiągnąć nadzwyczaj skutecznie (s. 359), choć trzeba tu obiektywnie przyznać, że jego książka jest bezsprzecznie dobrze napisaną i pasjonującą lekturą, a całą debatę wokół jej tez Wolff-Powęska ocenia nadzwyczaj rzetelnie i obiektywnie.

Uwaga ta dotyczy też debaty trzeciej, czyli sporu Walser-Bubis. W jej analizie uwagę czytelników chyba najbardziej mogą przykuć rozważania o „historycznej żałobie”, które zresztą stanowią wartościowe wprowadze- 
nie do omówienia debaty czwartej, czyli konfliktów wokół berlińskiego Pomnika Pomordowanych Żydów Europy. W tym przypadku za najbardziej interesujące można uznać przypomnienie przez poznańską uczoną tyle przedziwnych, co absurdalnych dyskusji dotyczących „konkurowania” w „hierarchizowaniu” czy „klasyfikowaniu” ofiar narodowego socjalizmu (s. 382, 386-387). Przy tym Wolff-Powęska przedstawiła bardzo uczciwie i dokładnie wszelkie kontrowersje (choćby artystyczne), które ten pomnik rzeczywiście wywołał (i wywołuje nadal).

W ostatnim podrozdziale, swoistym podsumowaniu rozdziału czwartego, „Ile przeszłości w pamięci?”, widoczna jest nie tylko duża erudycja autorki, ale również nadzwyczaj uważne studiowanie wszelkich toczących się pomiędzy Renem a Odrą dyskusji. Wolff-Powęska ma też rację, formułując tezę, że w przypadku kontynuacji wielu sporów odnoszących się do nazistowskiej przeszłości niemieckiego narodu obecna republika berlińska jest nieodrodną dziedziczką republiki bońskiej (s. 397).

W ostatnim rozdziale recenzowanej publikacji Wolff-Powęska pochyliła się nad konkretnymi niemieckimi „świętami pamięci”. Pierwszy jego podrozdział („Pamięć jak rytuał”) to przede wszystkim świetne wprowadzenie $\mathrm{w}$ temat. Została $\mathrm{w}$ nim zaprezentowana rytualna strona pamięci, w tym także ewolucja samego pojęcia rytuału, jego istota oraz historia od czasów prehistorycznych do współczesnych. W podrozdziale drugim zostały omówione różne aspekty jednego z owych niemieckich „świąt”: 8 maja. W jego podtytule zostało ono inteligentnie określone jako „dialektyka klęski i wyzwolenia”, a na szczególne uznanie zasługuje większa niż w pozostałych fragmentach tej książki liczba odwołań do zapisanych relacji i odczuć „Zwykłych”, „prostych” obywateli. Prawie na samym wstępie bardzo trafnie postawiono też pytania dotyczące licznych problemów samookreślenia się Niemców w 1945 r. (s. 416), czyli w obliczu końca wojny i ogólnonarodowej klęski, a także sformułowano słuszne spostrzeżenie, że ten 8 maja poszczególni Niemcy musieli przeżywać w bardzo różnoraki sposób, a największy na to wpływ miało ich położenie w tym dramatycznym momencie. Bardzo dokładnie, aż na 20 stronach (s. 420-440), autorka omówiła „świętowanie” 8 maja w dwóch niemieckich państwach. W NRD były to reglamentowane przez władze i mocno „nadęte” uroczystości, a w drugim zaś, pluralistycznym i demokratycznym NRF, zwracano uwagę na wielo- 
znaczność ocen wydarzeń związanych z tą datą. W państwie zachodnioniemieckim interpretacja wydarzeń z maja 1945 r. była ściśle zależna od poglądów politycznych wypowiadających sądy, zaskakująco zmieniających się pomiędzy 1949 a 1990 r. opinii. Aby nastąpiła w tym względzie odczuwalna i widoczna zmiana, potrzeba było aż 40 lat - dopiero obchody z 1985 r. stały się tu pewnym przełomem. Od tego momentu do debaty tej nie dodano właściwie nic nowego, również w zjednoczonych w $1990 \mathrm{r}$. Niemczech. Warte odnotowania jest tu jedynie większe koncentrowanie się Niemców - w związku z obchodami pięćdziesiątej i sześćdziesiątej rocznicy zakończenia wojny - na własnych ofiarach (bombardowań, masowych gwałtów na kobietach czy wypędzeń ze Wschodu). Przy tej okazji zostały przypomniane dwie naprawdę ważne publikacje niemieckich autorów, wydane zresztą również $\mathrm{w}$ Polsce ${ }^{* *}$, oraz pełne emocji dyskusje, jakie one wywołały (s. 448-450). W związku z kontrowersyjną książką Jörga Friedricha Wolff-Powęska nie dostrzega wprawdzie, że pod względem naukowym jest to dzieło bardzo solidnie opracowane, a na dodatek literacko sprawnie napisane, lecz potrafi przyznać, że Pożoga. Niemcy pod bombami 1940-1945 „stała się z miejsca bestsellerem” (s. 449).

Równie godny uwagi jest kolejny podrozdział recenzowanej książki poznańskiej badaczki. „Noc kryształowa - Holocaust jako dylemat tożsamości” otwiera interesującą, choć chyba nieco przydługą (aż 12 stron), prezentację historycznego tła i skutków wydarzeń z listopada 1938 r. Tu jednak wkradły się błędy (zapewne przy korektach), gdyż „doniesienia o zamachu w Paryżu zbiegły się” nie z „obchodami piętnastej rocznicy zamachu na Hitlera”, lecz z rocznicą próby jego zamachu, który do historii przeszedł pod nazwą puczu monachijskiego. Nie byłbym też pewien tego, że noc kryształowa rzeczywiście „została zaplanowana i starannie wyreżyserowana”, choć wiele - bardziej faktów niż źródeł - może na to wskazywać. W tym podrozdziale znów mamy do czynienia z niewątpliwie udaną prezentacją wielu niuansów stosunku Niemców (znów zarówno z Niemiec Wschodnich, jak i Zachodnich) i ich władz do rocznicy nocy kryształowej, chociaż autorka nie dostrzegła przynajmniej jednej kwestii. Mianowicie: wydarzenia z listo-

** W. G. Sebald, Wojna powietrzna i literatura: wyktady, Warszawa 2012; J. Friedrich, Pożoga. Niemcy pod bombami 1940-1945, Warszawa 2011. 
pada 1938 r., a także - w przypadku zagadnień żydowskich - wszelkie inne z lat 1933-1939 zostały (i są nadal) niejako „zepchnięte w cień”, a w społecznej świadomości nawet zapomniane, w wyniku tego wszystkiego, co spotkało Żydów (rzecz jasna nie tylko niemieckich) już w wojennych latach zagłady.

W podrozdziale czwartym - „Wojna przeciw Polsce w niepamięci niemieckiej" - autorka zauważa i obiektywnie analizuje niedostrzeganie lub minimalizowanie w Niemczech polskiego wątku ofiar narodowego socjalizmu. Jednocześnie wymienia ona grupy, które Polaków z tej pamięci „wypierają”. Obecnie to już nie tylko Żydzi, ale w ostatnich latach również Cyganie, a nawet homoseksualiści i ofiary medycznych eksperymentów (s. 484). Pisząc dość obszernie o niemieckich uprzedzeniach wobec Polski i Polaków, autorka nie przypomina fundamentalnej w tej kwestii (choć omawiającej wzajemne postrzeganie jakby „z drugiej strony”) pracy Wojciecha Wrzesińskiego $^{* *}$. Nie ma jej też w bibliografii, aczkolwiek wymieniono w niej dwie inne, dla tego tematu mniej istotne publikacje wrocławskiego historyka. Poświęcając wiele uwagi prezentacji istoty antypolskich animozji w republice weimarskiej, autorka nie wspomina też słowem o kilkuletnim i niezwykle - z politycznego punktu widzenia - istotnym ociepleniu polsko-niemieckich stosunków, które nastąpiło właśnie w pierwszych latach rządów Hitlera. W końcowych partiach tego podrozdziału (i całej książki) napotykamy jeszcze na interesujące omówienie niemieckiej niewiedzy czy też ignorancji na temat Polski. Może tu jednie zastanawiać, co autorka miała na myśli, pisząc, że „granica przyjaźni” z NRD była „nieprzepuszczalna” (s. 491). Przecież w latach siedemdziesiątych obywatelom Polski Ludowej i Niemiec Wschodnich do jej przekroczenia wystarczały zwykłe dowody osobiste, a po stanie wojennym i pozornej „normalizacji” w Polsce np. wymiana młodzieży też odbywała się na imponująca, wcześniej niespotykaną skalę. Natomiast na uznanie zasługuje przypomnienie przez Wolff-Powęską roli, jaką w żmudnej budowie polsko-niemieckiego pojednania spełniały przez kilkadziesiąt lat kręgi polskich i niemieckich chrześcijan, nierzadko

${ }^{* * *}$ W. Wrzesiński, Sasiad. Czy wróg? Ze studiów nad ksztattowaniem obrazu Niemca w Polsce w latach 1795-1939, Wrocław 1992. 
związane z hierarchami poszczególnych Kościołów, w tym przede wszystkim katolickiego.

Oprócz tych licznych kwestii szczegółowych, lektura książki WolffPowęskiej powinna inspirować do sformułowania wniosków oraz opinii o znacznie szerszym i ogólniejszym charakterze. Już w wstępie zwracają uwagę zapewnienia autorki, że jej dzieło, niejako programowo, nie posiada podsumowania czy też „konkluzji”, gdyż jego temat „jest nadal otwarty” (s. 18). Należy się tu zgodzić, że na pewno kwestia stosunku Niemców do narodowosocjalistycznego dziedzictwa III Rzeszy nie jest zamknięta i chyba zawsze taką pozostanie, chociaż oczywiście stosunek kolejnych pokoleń w tym szczególnie tych, dla których lata 1933-1945 stały się i staną już tylko historią - będzie się zmieniał. W naukowej publikacji brak konkluzji, reasumpcji, podsumowania jest jednak kontrowersyjny, a w przypadku książki Wolff-Powęskiej na dodatek nie do końca zgodny z prawdą, gdyż w praktyce owe konkluzje napotykamy w jej świetnej książce wielokrotnie. Dotyczą one licznych treści omawianych w poszczególnych fragmentach tego dzieła: np. znajdują się już we wstępie w 11 tezach pracy (s. 12-15), w analizie (bardzo zresztą ważnej i trafnej) dotyczącej zadań historyka we współczesnym świecie (s. 93-94) czy przy omówieniu czynników, które w zjednoczonych już po 1990 r. Niemczech doprowadziły do „ewolucji pamięci komunikatywnej w kierunku pamięci kulturowej” (s. 332-334). Przez podejrzliwych czytelników (oby ich zawsze było jak najwięcej) ów rzekomy brak konkluzji może być potraktowany jako pewien wybieg, będący skutkiem obaw autorki, że być może nie za dużo udało się w praktyce zbadać i wyjaśnić. Tak jednak na pewno nie jest, chociaż wypada zadać sobie pytanie: czyja właściwie pamięć jest w tej książce analizowana? Niby konkretnego narodu, ale czy przypominani i cytowani przede wszystkim historycy, politycy, kulturoznawcy, filozofowie, pisarze to już jest cały naród czy tylko jego część? A może po prostu tylko jego elity albo jego mniejsze lub większe, zasłużone lub też niezasłużone autorytety? Prócz stosunkowo nielicznych wyjątków trudno ich opinie uznać za prezentację stosunku zwykłych Niemców do nazistowskiej przeszłości. Badanie zbiorowej pamięci całych grup, szczególnie tak licznych i znaczących jak narody, a na dodatek w tak bolesnej kwestii jak dziedzictwo dyktatur i zbrodni, to na dodatek zadanie tyle odważne, co ryzykowane. Jest to wejście na bardzo chybotliwy 
most, choć efekt w przypadku książki Pamięć - brzemię i uwolnienie wart był tego wysiłku i niebezpieczeństw.

Przede wszystkim już ten doskonale skonstruowany tytuł w pewien sposób skłania uważniejszych czytelników do zadawania sobie przy lekturze każdej prawie strony tej książki przynajmniej trzech ściśle z nim związanych pytań: jak wyglądała owa niemiecka „pamięć” 12 lat III Rzeszy? na ile ciężkie było po niej niemieckie „brzemię”? oraz na ile nastąpiło od niej ich „uwolnienie” w czasie ostatnich prawie 70 lat? W niemałym stopniu próbę wyjaśnienia tych zagadnień Wolff-Powęska podjęła już w prawie stustronicowym i bez wątpienia erudycyjnym rozdziale pierwszym. Można tu jedynie zastanawiać się, czy tych rozważań o charakterze wprowadzającym w temat, a dotyczących „terminologii i teoretyczno-definicyjnych podstaw” (s. 17) nie należałoby uzupełnić o kwestie ściśle metodologiczne, czyli konkretne wyjaśnienie metod, narzędzi, technik badawczych, przy pomocy których autorka będzie dążyć do realizacji również wymagających doprecyzowania celów tej pracy. Inną rzeczą jest to, czy ta metodologia byłaby faktycznie wykorzystana w kolejnych, dotyczących już meritum tematu, rozdziałach. W czasie ich lektury nieraz można się zastanawiać, czy owa „pamięć” oraz jej „brzemię” i „uwolnienie” od niej są w ogóle w jakikolwiek sposób możliwe do naukowej weryfikacji. Przy tym za godne pochwały należy uznać wielokrotne (i to już w rozdziale pierwszym) dostrzeganie ścisłej zależności „pamięci', czy też może bardziej „tożsamości”, od pojęć tak istotnych jak „naród” i „nacjonalizm”.

Jak już wspomniałem, w wykładzie zasadniczym dla tematu omawianej publikacji (poszczególne podrozdziały rozdziałów II-IV) przyjęto układ chronologiczny. Autorka wprawdzie zaznacza, „iż w uzasadnionych przypadkach treść książki wykracza poza nakreślone granice czasowe” (s. 17), to jednak i tak w wielu jej fragmentach napotykamy chyba zbyt duży rzeczowy i chronologiczny chaos, aczkolwiek niewątpliwie zaprezentowany ciekawie i z wielką kulturą słowa. Wspominając tu o chronologii, można dodać, że nieco mało uwagi poświeciła Wolff-Powęska ewolucji owej tytułowej „pamięci” w odniesieniu do poszczególnych pokoleń Niemców (inną rzeczą jest dociekanie, czy w ogóle i na ile jest to możliwe przy zastosowaniu metod naukowych). Poza tym można zastanowić się, czy nie warto byłoby cofnąć się chronologiczne do lat 1933-1945 oraz pokusić się o poświęcenie 
jednego z rozdziałów (chyba najlepiej drugiego) lub podrozdziałów „polityce pamięci” lub „polityce historycznej” III Rzeszy. W końcu 1945 r. stał się tu punktem wyjścia do dalszych rozważań na temat „pamięci” Niemców, a wtedy, szczególnie wówczas najmłodsi (dziś najstarsi) z nich nie pamiętali (lub pamiętali bardzo słabo) czasy cesarstwa i republiki weimarskiej. Być może jest to jednak temat na odrębną oraz obszerną publikację.

Natomiast za jak najbardziej słuszne należy uznać liczne wysiłki WolffPowęskiej, konsekwentnie dążącej do w miarę dokładnego omówienia „dodatkowego" jakby problemu społeczeństwa dawnego NRD, czyli rozliczenia przeszłości i niewątpliwych zbrodni „pierwszego w dziejach państwa niemieckich robotników i chłopów". Wytrwale poszukuje ona pewnych analogii pomiędzy problemem „niemieckiej pamięci” wobec nazizmu a komunistycznym dziedzictwem części narodu po $1990 \mathrm{r}$. W związku z tym tematem autorka zauważyła i bardzo interesująco porównała kwestie niemieckich rozrachunków z nazistowską i komunistyczną przeszłością (kilkakrotnie analizując z jednej strony denazyfikację powojenną, a z drugiej dekomunizację wschodnich landów po 1990 r.), a także - w podrozdziale „Niemieckie przełomy 1945-1990" - przeprowadziła interesujące porównanie istoty dwóch totalitaryzmów: w III Rzeszy i w NRD (s. 325-334).

Dla udokumentowania prezentowanych w swojej książce tez WolffPowęska skorzystała głównie z literatury przedmiotu oraz - pod względem różnorodności - ze stosunkowo niewielkiej liczby źródeł (głównie pisanych, np. relacji, wspomnień, artykułów itd.). W swoich badaniach w niedużym stopniu skorzystała z ikonografii, np. dzieł sztuki, w tym obrazów, rysunków satyrycznych, a przede wszystkim dzieł kinematografii. Jako wyjątki można tu wymienić bardzo ciekawe przypomnienie „bohaterów seriali z ilustrowanych pism" z lat pięćdziesiątych, którymi byli niemieccy żołnierze, młodzi i pełni fantazji, w tym też zbrodniarze z SS (s. 263-265), i bardzo przekłamanego w tych opowieściach obrazu wojny, w tym krajów okupowanych. Z dzieł filmowych autorka nieco więcej uwagi poświęca jedynie amerykańskiej produkcji Holocaust, która była emitowana w zachodnioniemieckiej telewizji w latach 1978-79 i miała olbrzymią, kilkunastomilionową oglądalność (s. 297-300).

Natomiast znaczącym atutem recenzowanej książki jest to, że w całej pracy autorka zadała wiele bardzo ważnych pytań, które mogą być inspira- 
cją do dalszych badań, przede wszystkim zagadnień jeszcze bardziej szczegółowych. Poza tym można w czasie jej lektury odnieść też wrażenie, jakby autorka (a także wielu spośród cytowanych przez nią Niemców) problem niemieckiego uporania się z mrokami nazistowskiej przeszłości starała się zbyt często ograniczać wyłącznie do zbrodni Holocaustu. Szczególnie dotyczy to dwóch ostatnich rozdziałów. W tym przypadku badaczka przyjmuje więc - czasami i zapewne bezwiednie - reguły gry, w której zbrodnie, katów i ofiary ogranicza się tylko do kwestii związanych z zagładą europejskich Żydów. Z takim jednowymiarowym traktowaniem zbrodni narodowego socjalizmu wypada raczej polemizować, jest to szczególnie obowiązkiem historyków polskich. Wolff-Powęska wprawdzie kilkakrotnie zauważa, że niemieckie zbrodnie to nie tylko Holocaust, ale raczej niezbyt stanowczo i sugestywnie, jakby bez wiary, że możliwe jest skuteczne przeciwstawianie się temu, tak powszechnemu ich merytorycznemu zawężaniu. Można też polemizować z opinią autorki, że „pamięć holocaustu” stała się „mitem założycielskim republiki berlińskiej” (s. 484). Tych mitów było więcej, choć wśród pamiętanych ofiar narodowego socjalizmu niewątpliwie Żydzi zajmują szczególną pozycję. Kilkakrotnie i głównie w związku z tym WolffPowęska wspomina o poprawności politycznej panującej w Niemczech, posiadającej ścisły związek z nazistowską przeszłością. Niestety jednocześnie nie podaje żadnych przykładów ani nie wspomina o negatywnych skutkach tej informacyjno-komunikacyjnej patologii współczesnych nam czasów.

Pisząc o niemieckiej „Pamięci” oraz jej „brzemieniu” i „uwolnieniu” od niej, być może nieco więcej uwagi należało też poświęcić wypędzonym. Ta kilkumilionowa grupa (a potem, w kolejnych dziesięcioleciach jej liczni potomkowie) zawsze posiadała znaczący wpływ na toczące się Niemczech dyskusje o nazistowskiej przeszłości. Przecież jej doświadczenia i oceny przeszłości nieraz różniły się od głoszonych przez rodaków, którzy nigdy nie zostali zmuszeni do opuszczenia swoich ukochanych Heimatów. Jednak częściowo i dość logicznie autorka tłumaczy (przypis 13, na s. 336) przyczyny pominięcia tego istotnego, ale jej zdaniem bardzo „rozciągniętego” $\mathrm{w}$ czasie i przede wszystkim upolitycznionego problemu.

Na zakończenie omówienia kwestii o bardziej ogólnym charakterze dodam tylko, że może warto było w recenzowanej książce wspomnieć, że dla obciążonego narodowego samopoczucia Niemców z republiki boń- 
skiej (1949-1990) ważne były nie tylko sukcesy ekonomiczne "gospodarczego cudu", ale również niektóre osiągnięcia w innych dziedzinach, chociażby w coraz popularniejszym sporcie (w NRD był to przecież prawie propagandowy „przemysł”), w tym też to niespodziewane zwycięstwo w Mistrzostwach Świata w Piłce Nożnej w 1954 r. W tej dziedzinie niewątpliwymi sukcesami Niemców z zachodniej części podzielonego państwa, które zresztą znacznie podnosiły ich oceny w oczach innych narodów (oraz niewątpliwie również własną samoocenę), były też Igrzyska Olimpijskie w Monachium w 1972 r. oraz Mistrzostwa Świata w Piłce Nożnej w 1974 r.

Już w ostatecznej konkluzji, podsumowując recenzję, wypada stwierdzić, że w przypadku książki Pamięć - brzemię i uwolnienie. Niemcy wobec nazistowskiej przesztości (1945-2010) mamy do czynienia z publikacją na pewno wybitną, choć w licznych fragmentach niełatwą do jednoznacznej oceny. Bywa ona „o wszystkim” i jednocześnie jakby bez konkretnego problemu do rozważenia, chwilami jest więc prawie dziełem postmodernistycznym. Jest to może przypadek podobny do wspominanego przez autorkę postulatu „wzywającego do kreowania trzeźwego obrazu epoki hitlerowskiej”, w którym też można „zawrzeć wszystko i nic” (s. 131). Jednak całość czyta się świetnie, co jest efektem nie tyle solidnych badań, co erudycji i językowo-pisarskiej sprawności autorki. Jej dzieło ukazuje nam w pełni, jak wieloaspektowy, bogaty w fakty i odczucia oraz skomplikowany był i jest nadal nazistowski fragment niemieckiej „pamięci” (a może „niepamięci”) z ostatniego siedemdziesięciolecia.

Z lektury tej książki płynie jeszcze ważna i warta szerokiego rozpropagowania nauka, a przy tym - ostrzeżenie. Mianowicie: chyba każdy czytelnik winien się zastanowić nad tym, do czego może prowadzić socjalizm i to nie tylko ten w opisywanej przez Wolff-Powęską brunatnej i narodowej odmianie. Warto też wspomnieć, że na nową - po latach 1989-1990 - wyjątkowo dobrą jakość polsko-niemieckiej koegzystencji oraz jej przyszłość autorka recenzowanej publikacji patrzy z dużym optymizmem. Trudno stwierdzić, na ile może on być uzasadniony, szczególnie w momencie, gdy z takim pietyzmem i poświęceniem skonstruowana Unia Europejska balansuje na krawędzi przepaści. 